University of Nebraska - Lincoln

DigitalCommons@University of Nebraska - Lincoln

1979

\title{
Update of National and State Programs Presently Underway to Curb Point and Nonpoint Sources of Water Pollution from Animal Production Facilities
}

Donald F. Smith

Environmental Protection Agency, Washington, DC

Follow this and additional works at: https://digitalcommons.unl.edu/usepapapers

Part of the Civil and Environmental Engineering Commons

Smith, Donald F., "Update of National and State Programs Presently Underway to Curb Point and Nonpoint Sources of Water Pollution from Animal Production Facilities" (1979). U.S. Environmental Protection Agency Papers. 56.

https://digitalcommons.unl.edu/usepapapers/56

This Article is brought to you for free and open access by the U.S. Environmental Protection Agency at DigitalCommons@University of Nebraska - Lincoln. It has been accepted for inclusion in U.S. Environmental Protection Agency Papers by an authorized administrator of DigitalCommons@University of Nebraska - Lincoln. 


\title{
UPDATE OF NATIONAL AND STATE PROGRAMS PRESENTLY UNDERWAY TO CURB POINT AND NONPOINT SOURCES OF WATER POLLUTION FROM ANIMAL PRODUCTION FACILITIES
}

\author{
Donald F. Smith \\ Environmental Protection Agency, Washington, DC 20460
}

(Key Words: Water Pollution, Animal Production, Facilities, National and State Programs)

P.L. 92-500, The Federal Water Pollution Control Act Amendments of 1972, has provided two mechanisms for the control of water pollution from animal production facilities. Point source controls require that confined animal production facilities apply for a NPDES permit in order to operate. Nonpoint source controls, as established by State and area-wide water quality management programs, are to be developed around the concept of "Best Management Practices."

Presently (7/26/77), 1,275 permits are administered by EPA or the States to control point source discharges from beef cattle, dairy cattle, hogs, sheep and lambs, turkeys, laying chickens, broiler chickens, horses, et cetera. In the nonpoint source area within the State and areawide 208 water quality management agencies, 30 areawide agencies in 19 States have recognized water quality problems resulting from animal production facilities (7/21/77). These agencies are to propose controls through "best management practices" for their respective animal production facility problems. By November, 1978 all Statewide 208 agencies are to have a completed water quality management plan which outlines the controls needed to curb water pollution from the priorities identified.

According to USDA estimates, there are approximately 718,800 "animal feeding operations" in the United States (1). Of these, 94,500 are "concentrated animal feeding operations" which fall under the NPDES permit program regulations of March 18, 1976. The

\footnotetext{
${ }^{1}$ Paper presented as part of the Symposium on Alternatives in Animal Waste Utilization at Annual Meeting of the American Society of Animal Science, University of Wisconsin, Madison, July 23 to 27, 1977.
}

remaining 624,300 animal feeding operations are considered nonpoint in nature and will be evaluated through the water quality management program of each State. These "point" and "nonpoint" sources of pollution have been defined and discussed as follows.

1. Point source- “. . . any discernible, confined and discrete convey and, including, but not limited to any pipe, ditch, channel, tunnel, conduit, well, discrete fissure, container, rolling stock, concentrated animal feeding operation, or vessel or other floating craft, from which pollutants are or may be discharged." (P. L. 92-500, Sec. 502 (14), "General Definitions").

Federal Register, Vol. 41, Part 125.51, Marcb 18, 1976

"Subpart F- Special Programs

$\oint 125.51$. Concentrated Animal Feeding Operations.

(a) Definitions. For the purpose of this subpart:

(1) The term "animal feeding operation" means a lot or facility (other than an aquatic animal production facility) where the following conditions are met:

(i) Animals have been, are or will be stabled or confined and fed or maintained for a total of 45 days or more in any 12 -month period, and

(ii) Crops, vegetation, forage growth or post-harvest residues are not sustained in the normal growing season over any portion of the lot or facility.

Two or more animal feeding operations under common ownership are deemed to be a single animal feeding operation if they are adjacent to each other or if they utilize a common area or system for the disposal of wastes.

(2) The term "concentrated animal feeding operation," means an animal feeding operation which meets the criteria set forth in either 
paragraphs (a) (2) (i) or (ii) of this section.

(i) More than the numbers of animals specified in any of the following categories are confined:

(a) 1,000 slaughter and feeder cattle,

(b) 700 mature dairy cattle (whether milked or dry cows),

(c) 2,500 swine weighing over 25 kilograms,

(d) 500 horses,

(e) 10,000 sheep or lambs,

(f) 55,000 turkeys,

(g) 100,000 laying hens or broilers (if the facility has continuous over-flow watering),

(h) 30,000 laying hens or broilers (if the facility has a liquid manure handling system),

(i) 5,000 ducks, or

(j) 1,000 animal units; or

(ii) More than the following numbers and types of animals are confined:

(a) 300 slaughter or feeder cattle,

(b) 200 mature dairy cattle (whether milked or dry cows),

(c) 750 swine weighing over 25 kilograms,

(d) 150 horses,

(e) 3,000 sheep,

(f) 16,500 turkeys,

(g) 30,000 laying hens or broilers (if the facility has continuous over-flow watering),

(h) 9,000 laying hens or broilers (if the facility has a liquid manure handling system),

(i) 1,500 ducks, or

(j) 300 animal units, and either one of the following conditions are met:

(k) Pollutants are discharged into navigable waters through a man-made ditch, flushing system or other similar man-made device; or

(l) Pollutants are discharged directly into navigable waters which originate outside of and pass over, across, through or otherwise come into direct contact with the animals confined in the operation.

Provided, however, that no animal feeding operation is a concentrated animal feeding operation as defined above if such animal feeding operation discharges only in the event of a 25-year, 24-hr storm event.

(3) The term "animal unit" means a unit of measurement for any animal feeding operation calculated by adding the following numbers: The number of slaughter and fecder cattle multiplied by 1.0 , plus the number of mature dairy cattle multiplied by 1.4 , plus the number of swine weighing over $55 \mathrm{lb}$ multiplied by .4, plus the number of sheep multiplied by .1 , plus the number of horses multiplied by 2.0 .
(4) The term "man-made" means constructed by man and used for the purpose of transporting wastes.

(b) Application for Permit. (1) Any person discharging or proposing to discharge pollutants from a concentrated animal feeding operation, who has not already done so, shail file an application with the Regional Adminstrator by September 1, 1976.

(2) (i) Each application must be filed on a Short Form B and completed in accordance with the instructions provided with such form.

(ii) In addition to the information requred in the Short Form B the Regional Administrator may require any applicant to submit such other appropriate information as the Regional Administrator deems necessary to proceed with the issuance of the permit.

(c) Case-by-Case Designation of Concentrated Animal Feeding Operations. Notwithstanding any other provision of this section, the Director or the Regional Administrator may designate as a concentrated animal feeding operation any animal feeding operation not otherwise falling within the definition provided in $\oint 125.51$ (a) (2) above. In making such designation the Director or Regional Administrator shall consider the following factors:

(1) The size of the animal feeding operation and the amount of wastes reaching navigable water;

(2) The location of the animal feeding operation relative to navigable waters;

(3) The means of conveyance of animal wastes and process waste waters into navigable waters;

(4) The slope, vegetation, rainfall and other factors relative to the likelihood or frequency of discharge of animal wastes and process waste waters into navigable waters; and

(5) Other such factors relative to the significance of the pollution problem sought to be regulated.

Provided, however, that no animal feeding operation with less than the numbers of animals set forth in paragraph (a) (2) (ii) of this section shall be designated as a concentrated animal feeding operation unless such animal feeding operation meets either of the following conditions:

(6) Pollutants are discharged into navigable waters through a manmade ditch, flushing system or other similar man-made device; or

(7) Pollutants are discharged directly into navigable waters which originate outside of and 
pass over, across, through or otherwise come into direct contact with the animals confined in the operation. In no case shall a permit application be required from a concentrated animal feeding operation designated pursuant to this section until there has been an onsite inspection of the operation and a determination that the operation should and could be regulated under the permit program. In addition, no application shall be required from an owner or operator of a concentrated animal feeding operation designated pursuant to this section unless such owner or operator is notified in writing of the requirement to apply for a permit."

41 FR 11461, March 18, 1976.

\section{Nonpoint source}

a. Proposed rules-Concentrated Animal Feeding Operations; Federal Register, Vol. 40, No. 225, Thursday, Nov. 20, 1975, p.54185.

"COMMENT- The legislative history of the FWPCA indicates that those agricultural sources not within the above definition are presumptively nonpoint sources and therefore are not under the jurisdiction of the permit program. Thus, those animal feeding operations without measurable wastes discharged from a manmade drainage ditch, flushing system or other similar device; without a direct discharge into navigable waters traversing the operation; and with fewer than the cutoff numbers enumerated above are nonpoint sources, unless otherwise designated by the Regional Administrator pursuant to $\oint 125.51$ (c) as proposed below."

b. Proposed rules- Agricultural activities; Federal Register, Vol. 41, No. 36, Monday, February 23, 1976, p. 7964.

\section{INTENT OF REGULATIONS}

The intent of the regulations is to exclude from the NPDES permit program all natural runoff from agricultural land which results from precipitation events. Because most water pollution related to agricultural activities is caused by runoff resulting from precipitation events and is nonpoint in nature, it is not and should not be subject to the NPDES permit program as it has been administered to date. (The fact that weather may be modified to a limited extent by man's efforts, such as cloud -seeding, does not alter the nonpoint nature of water pollution resulting from precipitation events.)

Nonpoint sources tend to be characterized
TABLE 1. STATE PERMIT ACTIVITY AND AREAWIDE 208 AGENCY ACTIVITY WITH RESPECT TO ANIMAL PRODUCTION FACILITIES

\begin{tabular}{|c|c|c|}
\hline State & $\begin{array}{l}\text { Current } \\
\text { permits } \\
\text { (7/26/77) } \\
\text { issued by } \\
\text { EPA or } \\
\text { State }\end{array}$ & $\begin{array}{l}\text { Areawide } \\
208 \text { agencies } \\
\text { identifying } \\
\text { problems } \\
\text { to animal } \\
\text { production } \\
\text { facilities }\end{array}$ \\
\hline Alabama & 0 & $\cdots$ \\
\hline Alaska & $\mathbf{0}$ & $\ldots$ \\
\hline Arizona & 36 & $\ldots$ \\
\hline Arkansas & 2 & $\ldots$ \\
\hline California ${ }^{*}$ & 22 & $\ldots$ \\
\hline Colorado* & 166 & 2 \\
\hline Connecticut & 0 & $\cdots$ \\
\hline Delaware* & 1 & 1 \\
\hline Florida * & 10 & 4 \\
\hline Georgia & 2 & $\ldots$ \\
\hline Hawaii & 4 & $\cdots$ \\
\hline Idaho & 64 & $\ldots$ \\
\hline Illinois* & 26 & 2 \\
\hline Indiana* & 10 & 2 \\
\hline lowa* & 39 & 2 \\
\hline Kansas* & 219 & $\ldots$ \\
\hline Kentucky & 0 & $\ldots$ \\
\hline Louisiana* & 4 & $\ldots$ \\
\hline Maine* & 0 & 2 \\
\hline Maryland & 2 & 1 \\
\hline Massachusetts & 1 & $\cdots$ \\
\hline Michigan* & 1 & 1 \\
\hline Minnesota $*$ & 37 & 1 \\
\hline Mississippi* & o & $\ldots$ \\
\hline Missouri & 1 & $\ldots$ \\
\hline Montana & 40 & 1 \\
\hline Nebraska* & 389 & $\ldots$ \\
\hline Nevada* & 8 & $\ldots$ \\
\hline New Hampshire & 0 & 1 \\
\hline New Jersey & 0 & $\ldots$ \\
\hline New Mexico & 10 & $\ldots$ \\
\hline New York* & 0 & $\cdots$ \\
\hline North Carolina & 0 & $\ldots$ \\
\hline North Dakota* & 9 & $\ldots$ \\
\hline Ohio* & 2 & 1 \\
\hline Oklahoma & 15 & $\ldots$ \\
\hline Oregon* & 4 & 1 \\
\hline Pennsyivania & 0 & $\cdots$ \\
\hline Rhode Island & 0 & $\ldots$ \\
\hline South Carolina* & 0 & $\cdots$ \\
\hline South Dakota & 50 & 2 \\
\hline Tennessee & 0 & $\ldots$ \\
\hline Texas & 50 & 1 \\
\hline Utah & 14 & 1 \\
\hline Vermont* & $\mathbf{0}$ & $\ldots$ \\
\hline Virginia* & $\mathbf{0}$ & $\cdots$ \\
\hline Washington* & 10 & 1 \\
\hline West Virginia & $\mathbf{0}$ & $\ldots$ \\
\hline Wisconsin * & 0 & $\ldots$ \\
\hline Wyoming* & $\cdots$ & $\ldots$ \\
\hline Total & 1275 & 30 \\
\hline
\end{tabular}

* Those states with permit authority. 


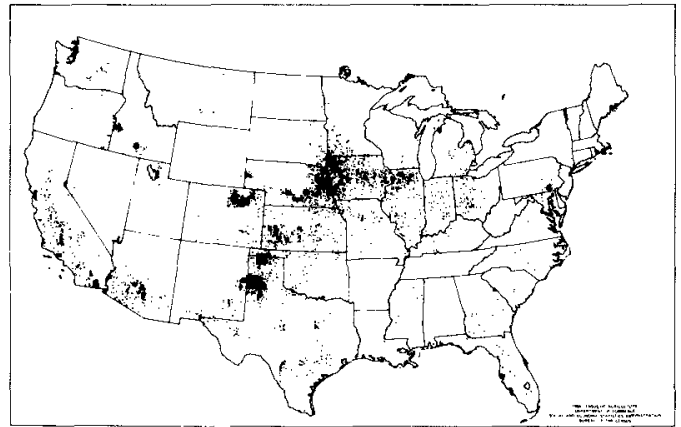

Figure 1. Cattle fattened on grain and sold for slaughter.

by three elements. First, the pollutants are conveyed by water the source of which is uncontrolled by any person; that is, the water pollution results from precipitation, natural flooding or snowmelt. Second, the pollution itself is not traceable to a discrete, identifiable source such as a facility or industrial process. The fact that this runoff may be channelled into a ditch or drain before entering navigable waters does not, in and of itself, make natural surface runoff a discharge from a point source. Third, the control of nonpoint source water pollution is generally best achieved by planning and management techniques rather than by end-of-pipe treatment to remove pollutants. End-of-pipe treatment, designed to meet specified effluent limitations, is often inappropriate for pollution control for nonpoint sources. Instead, planning and management techniques control and abate the nonpoint pollution before it is created and thus effectively limit and prevent polluants from reaching navigable waters."

The activity within EPA and the States with

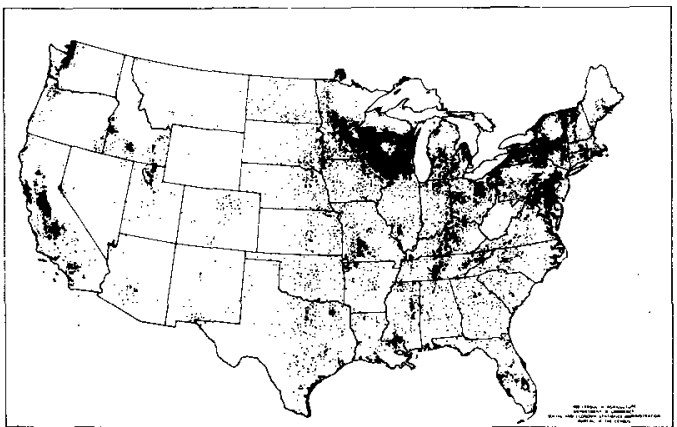

Figure 2. Milk cows.

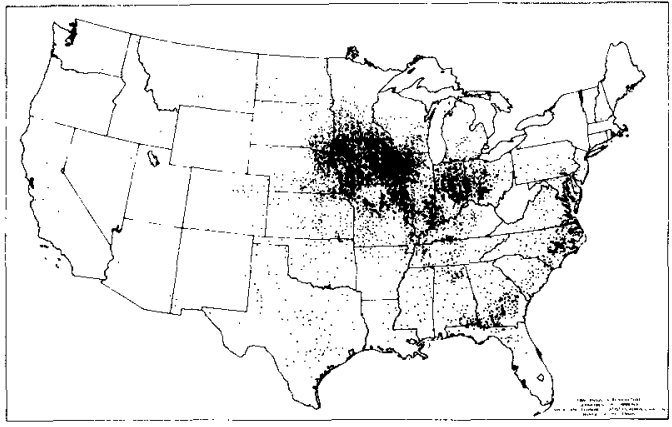

Figure 3. Hogs and pigs.

respect to point sources is outlined in table 1 . A total of 1,275 active permits (as of $7 / 26 / 77$ ) have been issued. According to USDA estimates (anonymous, 1976), this accounts for approximately $1.3 \%$ of the animal feeding operations in the U. S. Many more permit applications have been applied for, some have not been acted upon as yet, others hảve been judged as not requiring a permit.

Nonpoint sources of pollution resulting from animal production facilities are to be controlled through the "areawide waste treatment management planning process" as outlined in P. L. 92-500, Sec. 101(a) (5), Sec. 201 (a) \& (c), and Sec. 208.

Areawide and Statewide 208 water quality management planning programs are underway in all. States. Of the approximately 179 areawide 208 agencies, 30 have recognized water quality problems resulting from animal production facilities, both confined and grazing. Statewide 208 programs are just getting underway, therefore statistics are not available; however I would expect that nearly every State

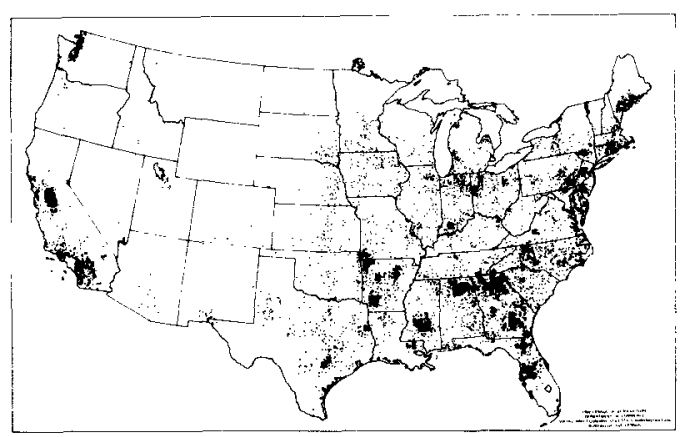

Figure 4. Chickens 3 months old or older. 


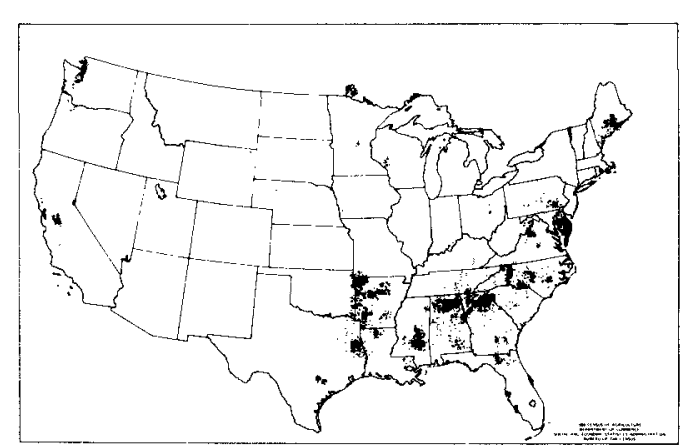

Figure 5. Broilers and other meat-type chickens.

will recognize animal production facilities as a potential water quality problem. As it is, every State regulates animal production facilities from a public health standpoint.

In the State and areawide water quality management plans, practical and professional input must be sought to help develop workable approaches to land management practices which, in turn, degrade water quality. Animal Scientists, both in the field and lab, have a role to play in this water quality management program. Your insight into the habits and needs of animals is invaluable where "best management practices" are being developed for water quality improvements.

The water quality in streams, rivers, lakes and oceans of the entire United States is being evaluated in State and areawide 208 programs. Where animal production facilities are predominant (figures 1 to 5) (Mulkey and Carlson, 1975), they more than likely will surface high on the list of priorities as established by these agencies. If your interest lies in the "animal production vs water quality impact" field, you should contact the responsible 208 agency in your geographical area and offer your services as reviewer, writer, et cetera.

\section{LITERATURE CITED}

Anonymous. 1976. Implications of EPA Proposed Regulations of November 20, 1975 for the Animal Feeding Industries." USDA Animal Waste Subcommittee, USDA, Washington, DC.

Mulkey, L. A. and C. W. Carlson. 1975. Control of Water Pollution from Cropland- A Manual for Guideline Development, Volume I; EPA-600/275-026a or ARS-H-5-1. 